\title{
Concept Map: Does It Increase Learning Motivation of Student?
}

\author{
Aisyiyah Dinnur Utami ${ }^{1}$, Eko Yuliyanto ${ }^{2 *}$, \\ 1,2, Study Program of Chemistry Education, Universitas Muhammadiyah Semarang \\ Corresponding Author. Email: ekoyuliyanto@unimus.ac.id
}

\author{
Keywords: \\ Learning model, \\ concept map, \\ atomic structure, \\ motivation, \\ learning outcomes.
}

\begin{abstract}
The learning model used by a teacher is a factor that supports the success of learning during the process of teaching and learning activities. The particular study aimed to determine differences in student learning outcomes and motivation before and after for learning using the concept map model in the material of chemical atomic structure for class X. This study used a quasi-experimental research method with the One Group Pretest-Posttest Design research design. The sample was 36 students from class $\mathrm{X}$ and selected using a purposive sampling technique. A test instrument was used to collect data of learning outcomes and a questionnaire used to collect data of student's motivation, and a pretest and posttest were carried out. Analysis of hypothesis test used Paired Sample T-Test. The results of this study were: (1) there were significant differences in term of student's learning outcomes before and after learning treated using a concept map model in chemistry subject for the material of the atomic structure, and (2) there was a decreasing in term of student's motivation before and after learning treated using concept map model in chemistry subject for the material of the atomic structure.
\end{abstract}

C2020 JSER. Yogyakarta State University

\section{INTRODUCTION}

Chemistry is science studies the natural phenomena, but more specifically, it studies the structure, composition, properties, and changes the matter, as well as the energy in the changing of the matter (Tasiwan et al, 2014, p.XX). Chemistry is needed for everyday life, but a lot of people consider chemistry as an uninteresting science because chemistry is closely related to abstract concepts, and the learning requires high reasoning (Wardhani et al., 2014). The number of abstract concepts of chemistry that must learn by students leads chemistry as one of the most difficult subjects for students. So, it requires a correct understanding of the basic concepts (Yunita et al, 2014, p. XXX).

Atomic structure is material in chemistry and teaches to students of class X SMA in the early semester. This material has characteristics, including (a) abstract (invisible), study about electrons, protons, neutrons, isotopes, isobars, isotones, and atomic models, (b) understanding the concept, namely configuration rules and atomic theory, and (c) application concept, namely configuration the electrons of atoms (Widiyowati, 2014). Concepts in atomic structure, such as determining the configuration of electrons, quantum numbers, and the periodic system of the elements, are abstract concepts, so it needs an easy way to understand the concepts, particularly, for the atomic structure concepts which are the basic concepts in understanding various other chemical concepts. Several concepts in the atomic structure that students tend unable to present are the atomic concepts of Dalton, Thompson, Rutherford, Bohr and wave mechanics, and the electron configuration of an ion (Fitriza and Gazali, 2017).

The success of the learning process always relates to teaching methods used by the teacher (Agustin et al, 2018). Besides, a teacher needs to use appropriate teaching methods in delivering material aiming the students interested in the learning. Students' interest in learning could make students achieve a better outcome.

The learning model used by a teacher is a factor that supports the success of learning during the process of teaching and learning activities. Also, it needs to consider the students' motivation. Motivation is an important psychological factor in the learning process. Motivation is a conscious effort to lead and maintain one's behavior to be motivated in taking action aiming to achieve certain 
results (Kurniawan et al, 2017). Motivation is generated through a stimulus situation with memory to influence students as to mechanical laws to reach the functions to direct, activate and increase student activity in the learning process (Tasiwan et al., 2014).

Learning methods that can increase the active role of students also can improve students' understanding of the material delivered by the teacher (Sunarto et al, 2011). Concept map is a way to develop meaningful teaching and learning strategies for students (Fachrurrozie and Sri W, 2010). The learning model of concept map is a teaching tool recommended by Ausubel (Burhanuddin, 2018).

Concept mapping is a method used to develop ideas and thoughts so that they can flow clearly and logically (Pribadi and Delfy, 2015). According to (Novak and Cañas, 2010), Concept Mapping is an effective tool to present visually a hierarchy of generalizations and to express the relationship of propositions in a system of interconnected concepts. The concept map is a way of facilitating in organizing information. The use of concept maps in learning activities provides opportunities for students to process information obtained through compile the concept mapping and discussion. The more students carry out discussion activities, the more students will have the opportunity to gain information (Shinta N et al, 2013). The development of the concept map is the Mind Mapping method, which is a learning method designed to develop students' knowledge by creative activities of arranging main ideas from a concept into a mind map that is easily understood by students (Darusman, 2014).

Assigning students to develop a concept map as well as a way of evaluation will provide more opportunities for students to be involved in the learning process (Wiyarsi and Sutiman, 2009).

Learning strategies of Concept map has benefits in enhancing meaningful learning and student's conceptual understanding (Taie, 2014). An effort in making effective learning is through involving the potential thoughts of the students in learning (Puspitayanti and Maryam, 2014). The ability of students to create concept maps may use to measure the learning outcomes of students, namely complete understanding (Maurisa and Abdullah, 2016).

Learning using concept maps is hopefully able to facilitate students in understanding or linking concepts to the material being studied, which improves student's motivation and learning outcomes. Muratni, et al. (2013) conclude that the application concept map in chemical bonding material can improve student's learning outcomes in class X, SMA Negeri I Telaga (Ismail et al, 2013).
In practice, there are steps to create a concept map aiming it is structured systematically and clearly. The steps in creating a concept map were: a) Studying material from the book, b) Determining the relevant concepts, c) Sorting the concepts hierarchically, starting from the most inclusive concept to the most specific concept, d) Arranging the concepts on a paper by placing the most inclusive concept at the very top, and e) Connecting the concepts with conjunctions.

The problem of this study based on the initial observations by researchers that most of the students of class X in one of the MAN (Islamic High School) in Semarang have difficulty in finding the core concepts and connecting the concept of material in chemistry learning.

\section{METHOD}

The research was a Quasi-Experimental method. The purpose of the quasi-experimental method is to obtain estimated information that can be obtained by actual experiments because the variables cannot be controlled or manipulated, so the validation of the research is not proper to be called a real experiment (Suryabrata, 2011: 116). In short, this study aimed to determine the differences in learning outcomes and student's motivation before and after using the concept map learning strategy in the material of the chemical atomic structure in class $\mathrm{X}$.

This research was conducted with students of class $\mathrm{X}$ at a MAN (Islamic High School) in Semarang in the odd semester of the 2019/2020 school year. This research was conducted from 5 August 2019 to 21 September 2019.

The population was 36 students of class $\mathrm{X}$ MIPA. The sample was one class due to limited conditions and time. In this case, one class played as a control class and experimental class. The sample was selected using a purposive sampling technique, which a technique determined the sample following with the required criteria.

This research design used One Group PretestPostest Design. Sugiyono (2012: 110) stated that the one group pretest and posttest design is a technique to determine the effects before and after treatment. In a chart, the one group pretest-posttest design was described in figure 1:

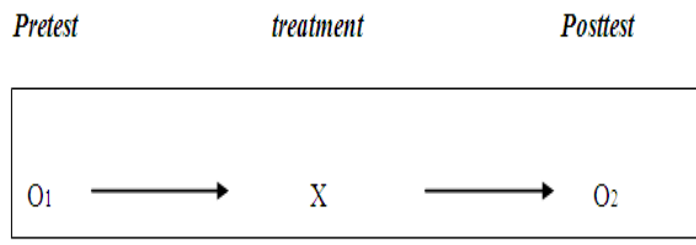

Figure 1. One group pretest-posttest design (Sugiyono, 2012: 110) 
Based on the research design, the following research procedures were: (1) Pretest before treatment in the experimental class, (2) Treatment of concept map learning, (3) Posttest after the treatment, and (4) Analysis of research data using statistical testing.

The independent variable was learning using concept map learning strategies in the atomic structure material. The concept of map learning strategy is an independent variable because it influences the change to other variables. Meanwhile, the dependent variable was the learning outcomes and motivation. Learning outcomes and learning motivation played as the dependent variables because they are influenced by the independent variables.

Data collection instruments were instruments of learning outcome (cognitive assessment) and questionnaires for motivation. The instrument was a multiple choice question aiming to find out the understanding of students to the chemical concept of the atomic structure material (W and Sutiman, 2009).

Analysis techniques of cognitive instrument and motivation questionnaires were: (1) validity test, determining the validity using a statistical test, and (2) reliability test, used to measure the accuracy of the instrument. The data analysis technique used the t-paired sample test, which was used to test data from the same subject but different treatments. Data processing used SPSS statistical testing.

\section{RESULT AND DISCUSSION}

The data of the study were student's learning outcomes and student's motivation before and after the treatment of concept map strategy in chemistry subject on the atomic structure material on class $\mathrm{X}$ MIPA in MAN in Semarang.

The first research procedure was spreading the pretest of 30 items learning outcomes and 35 statements for motivation instruments. The pretest carried out before treated the student with a concept map strategy. Based on the instrument validity test, if $\mathrm{r}$ count $>\mathrm{r}$ table declared valid $(\mathrm{r}$ table $=0.329 ; \mathrm{n}$ = 36). Then, the results of the validity test, 11 questions were valid, and 19 questions were invalid of a total of 30 questions on the learning outcomes instrument. Meanwhile, 23 questions were valid, and 12 questions were invalid of a total of 35 questions on the student motivation instrument. In the instrument reliability test, the learning outcomes obtained $r=0.850$ with $r$ table $=0.329(5 \%)$, which means that the learning outcome instrument was reliable. In sum, the instrument is valid and reliable used as a tool to test the effect of concept map learning strategies on student learning outcomes and motivation in the atomic structure material.

The second procedure was the treatment of the concept map learning strategy experiment for four face-to-face meetings. In the last meeting, it carried out a posttest with an instrument of learning outcomes and motivation following the valid test results. After the obtained posttest score, the normality test was performed as a prerequisite for analysis. The normality test used the KolmogorovSmirnov with the following results:

Table 1. Normality Test of Posttest Instrument

\begin{tabular}{cccc}
\hline Parameter & Sig & Alpha & Conclusion \\
\hline $\begin{array}{c}\text { Pretest Score of } \\
\text { Learning Outcome }\end{array}$ & 0,131 & 0,05 & Normal \\
$\begin{array}{c}\text { Posttest Score of } \\
\text { Learning Outcome } \\
\text { Pretest Score of } \\
\text { Motivation }\end{array}$ & 0,453 & 0,05 & Normal \\
$\begin{array}{c}\text { Posttest score of } \\
\text { Motivation }\end{array}$ & 0,507 & 0,05 & Normal \\
\hline
\end{tabular}

The results of the normality test on the instrument of learning outcomes and motivation, both pretest and posttest, the sig value obtained> 0.05 . It means that the instrument was normally distributed. As the instrument is normally distributed, it continued to the next test using the Paired Sample T-Test, which tests the differences in the mean of the two groups of data or paired samples. The results of the Paired Sample T-Test was presented as follows:

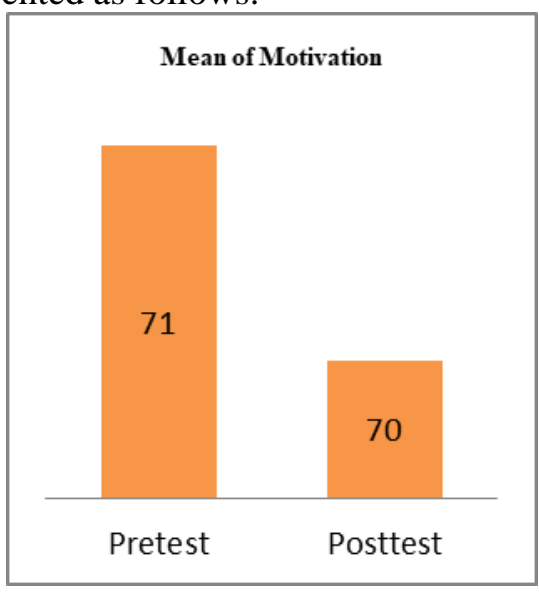

Figure 2. Students' Motivation 


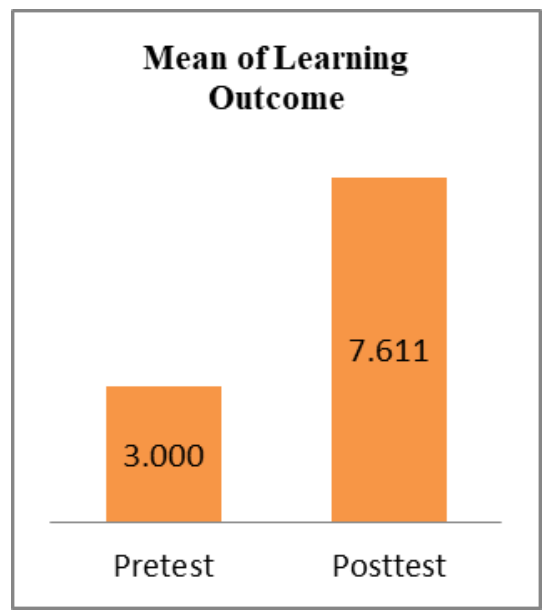

Figure 3. Diagram of Mean of Learning Outcome

Figure 2 showed a diagram of the mean of students' learning motivation on pretest and posttest with statistical calculations. The mean of the posttest was lower than the mean of the pretest, which was 71.08 for the pretest and 70.30 for the posttest. The possibility reason, the students did not fill out carefully the questionnaire due to there was a sudden visit from the health center. This factor is in line with previous research by Novianti. She states that environmental factors have an influence and affect students' concentration in learning (Novianti, 2019).

Students tended very interested in using concept map learning strategies during the experimental process that proved by the enthusiasm of the students in arranging a mind map, such students coloring in writing and chart to make it look more attractive. According to previous research, the appearance of colors or images can facilitate understanding and strengthen students' memory because of students like interesting reading with few descriptions but lots of pictures or colors (Hasanah et al, 2017). Moreover, Ngadiyan, using color for the brain can make mind mapping more live and adding energy to creative and fun thinking (Ngadiyan, 2018). Another observation obtained by the researcher during the 3rd meeting in the experiment of concept map learning strategy, a student stated expression:

"Mrs, do you like to create concept maps? It's okay, Mrs as it's more concise."

The researcher did not ask the question to each student, but, at that time, a student accidentally states it when the researcher explained the material using a concept map. This expression is one of the students' positive responses to the concept of map learning strategy.

Based on the theory, students' learning motivation affects student learning outcomes. Figure 3 shows a mean of students' learning outcomes at the pretest and posttest. The mean posttest of 7.61 was higher than the pretest of 3.00. In short, based on the instrument analysis test, there was an increase in students' learning outcomes in chemistry on the atomic structure material before and after using the concept map learning strategy.

At the beginning of the treatment, not all students were able to find the concepts in the material. They seem to have difficulty making concept maps so that some students still write down all the theoretical sentences they read. However, in the second experimental treatment, the students began to understand and were able to find the core concepts of the material into a concept map. Thus, the learning process is not only teacher-centered, but students can also develop a broader conceptual basis using their critical thinking skills, which they can improve learning outcomes.

Based on previous research (Redhana, 2010) concluded that concept map-based learning strategies were effective in improving students' critical thinking skills. Meanwhile, (Rosana 2014) also concluded that the critical thinking ability of students increases the students' learning outcomes.

Figure 4 was one of the results of the concept map made by the student.

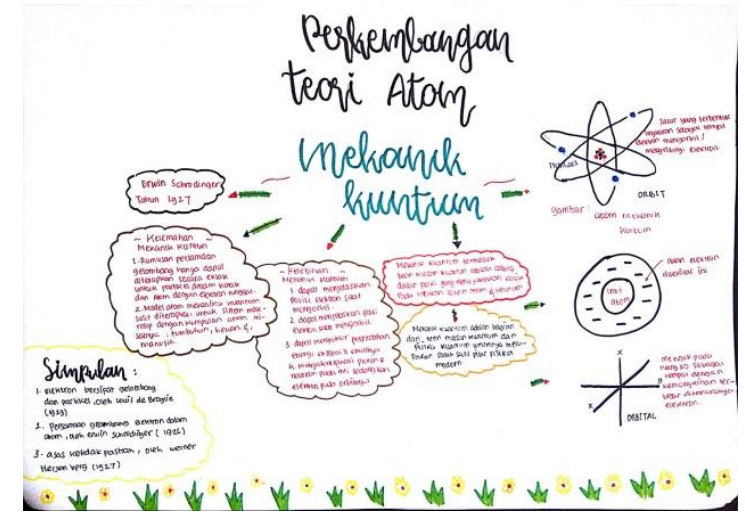

Figure 4. Example of concept map made by the students.

Students become creative in making mind maps through concept maps. Supported by Wiyarsi and Sutiman in their research that the task of drafting a concept map contains meaningful learning, assessing assignments, and involving student creativity, will increase students' motivation (Wiyarsi and Sutiman, 2009).

Concept maps prepared by students are arranged with colorful charts and writing to provide an attraction for students. Also, a practical strategy mind map in making material points according to student understanding can overcome difficulties in understanding the material. 


\section{CONCLUSION}

Based on the results and discussion, it concluded that there was an influence of chemistry learning motivation on concept map learning strategies that affect the students' learning outcomes in atomic structure material.

For further research, it should research two classes that play as control and experimental class, and add the learning meetings to conduct strategy experiments to achieve the maximized expected results.

Conclusions can be a generalization of research findings according to the problems. It can also be a recommendation for the next step or other studies.

\section{REFERENCES}

Agustin, A, and et al. (2018). Pengaruh Penggunaan Peta Konsep Berbasis Multilevel Terhadap Pemahaman Konsep Kimia SMA. Chemistry in Education, 7 (2), 8-13.

Burhanuddin. (2018). Penerapan Model Pembelajaran Peta Konsep Untuk Meningkatkan Hasil Belajar IPS Siswa Kelas VI SD Negeri 022 Jaya Mukti Kota Dumai. Jurnal PAJAR (Pendidikan dan Pengajaran), 2 (13), 1-16.

Darusman, R. (2014). Penerapan Metode Mind Mapping (Peta Pikiran) Untuk Meningkatkan Kemampuan Berpikir Kreatif Matematik Siswa Smp. Infinity Journal, 3 (2), 164.

Eryanti, E. (2015). Pengaruh Strategi Belajar Peta Konsep Terhadap Ketuntasan Belajar Matematika Siswa. Jurnal Pendidikan Matematika dan Matematika, 1(2), 45-58.

Fachrurrozie and Indah, F.S.W. (2010). Efektifitas Peta Konsep Dalam Pembelajaran Mata Kuliah Dasar Akuntansi. Jurnal Pendidikan Ekonomi Dinamika Pendidikan, V (2), 16579.

Fitriza, Z,. and Fauzana G. (2017). Pengembangan Modul Pembelajaran Kimia Berbasis Model Perubahan Konseptual Ed3U (Explore, Diagnose, Design, Discuss, Use) Terintegrasi Multi Representasi Pada Materi Struktur Atom. Jurnal Eksakta Pendidikan (Jep), 1(2), 64.

Hasanah, Nafida, N., Supeno, and Sri, W. (2017). Kekuatan Retensi Siswa SMA Kelas X Dalam Pembelajaran Fisika Pada Pokok Bahasan Momentum Dan Impuls Menggunakan Lembar Kerja Siswa Berbasis Mind Mapping. Jurnal Pembelajaran dan Pendidikan Sains, 2 (1), 25-32.
Ismail, Muratni, Lukman, and La A. (2013). Meningkatkan Hasil Belajar Ikatan Kimia Dengan Menerapkan Strategi Pembelajaran Peta Konsep Pada Siswa Kelas X Di SMA Negeri I Telaga. Jurnal Entropi, 8(1), 1-10.

Kurniawan, Budi, Ono, W., and Tatang, P. (2017). Studi Analisis Faktor-Faktor Yang Mempengaruhi Hasil Belajar Pada Mata Pelajaran Teknik Listrik Dasar Otomotif. Journal of Mechanical Engineering Education, 4 (2), 156.

Maurisa, Annisa M, and Herkules A. (2016). Hubungan Kemampuan Membuat Peta Konsep Dengan Hasil Belajar Siswa Di Kelas XI Pada Materi Pokok Sistem Eksresi Manusia. Jurnal Pelita Pendidikan, 4 (2), 15 19.

Ngadiyan. (2018). Pengaruh Strategi Mind Mapping T Erhadap Motivasi Dan Prestasi Belajar Siswa Mata Pelajaran Fikih Di Kelas VII MTsN 8 Gunungkidul. Jurnal Pendidikan Madrasah, 3 (3), 89-102.

Novak, Joseph D, and Alberto J.C. (2010). The Theory Underlying Concept Maps and How to Construct and Use Them. Práxis Educativa, 5 (1), 9-29.

Novianti, R. (2019). Pengaruh Lingkungan Belajar Terhadap Tingkat Konsentrasi Belajar Siswa Pada Mata Pelajaran Akidah Akhlak Di MAN 1 Palembang. Jurnal PAI Raden Fatah, 1 (1), $1-18$.

Pribadi, Benny A, and Refni D. (2015). Implementasi Strategi Peta Konsep (Concept Mapping) Dalam Program Tutorial Teknik Penulisan Artikel Ilmiah Bagi Guru. Jurnal Pendidikan Terbuka dan Jarak Jauh, 16 (2), 76-88.

Puspitayanti, N.P.Y, and Siti M. (2014). "Peta Pikiran Dan Peta Konsep. Jurnal Pendidikan dan Pengajaran, 47 (1), 11-21.

Redhana, I.W. (2010). Pengaruh Model Pembelajaran Berbasis Peta Argumen Terhadap Keterampilan Berpikir Kritis Siswa Pada Topik Laju Reaksi. Jurnal Pendidikan dan Pengajaran, 43 (17), 141-48.

Rosana, L.N. (2014). Pengaruh Metode Pembelajaran Dan Kemampuan Berpikir Kritis Terhadap Hasil Belajar Sejarah Siswa. Jurnal Pendidikan Sejarah, 3 (1), 34-44.

Shinta N, Gilang, Sukiswo Supeno E, and Siti K. (2013). Penerapan Peta Konsep Dalam Pembelajaran Untuk Meningkatkan Hasil Belajar Fisika Pada Pokok Bahasan Gerak Lurus Siswa Kelas VII SMP. Unnes Phsysic Eduation Journal, 2 (1), 7-14.

Sunarto, Wisnu, Woro S, and Eli S. (2011). Hasil Belajar Kimia Siswa Dengan Model Pembelajaran Metode Think-Pair-Share Dan 
Metode Ekspositori. Jurnal Inovasi Pendidikan Kimia, 2 (1), 244-49.

Taie, E.S. (2014). Concept Mapping as an Innovative Teaching Strategy to Enhance Cognitive Learning in Nursing Administration Course. International Journal for Innovation Education and Research, 2 (7), 11-25.

Tasiwan, S.E.N, and Hartono. (2014). Analisis Tingkat Motivasi Siswa Dalam Pembelajaran IPA Model Advance Organizer Berbasis Proyek. Jurnal Pendidikan IPA Indonesia, 3 (1), 43-50.

W, A., and Sutiman. (2009). Pengaruh Peta Konsep Terhadap Motivasi Dan Penguasaan Konsep Kimia Siswa Sma. Jurnal Pendidikan Kimia FMIPA UNY, 81-88.

Wardhani, A.I, M Masykuri, and Budi U. (2014). Pengaruh Pembelajaran Kooperatif Model Think Pair Share (TPS) Menggunakan Strategi Peta Konsep Dan Peta Pikiran Terhadap Prestasi Belajar Siswa Materi
Ikatan Kimia Kelas XI SMA Negeri 1 Karanganyar Tahun Ajaran 2013/2014. Jurnal Pendidikan Kimia, 3 (2), 36-44.

Widiyowati, I.I. (2014). Hubungan Pemahaman Konsep Struktur Atom Dan Sistem Periodik Unsur Dengan Hasil Belajar Kimia Pada Pokok Bahasan Ikatan Kimia. Pancaran, 3 (4), 99-116.

Wiyarsi, Antuni, and Sutiman. (2009). Pengaruh Peta Konsep Terhadap Motivasi Dan Penguasaan Konsep Kimia Siswa SMA. Jurnal Pendidikan Matematika dan Sains, 14 (2), 81-88.

Yunita, Luki, and et al. (2014). Pemanfaatan Peta Konsep (Concept Mapping) Untuk Meningkatkan Pemahaman Siswa Tentang Konsep Senyawa Hidrokarbon. EDUSAINS, VI (1), 2-8. 